\title{
Implementation of International Relations on Illegal Fishing Activities by Chinese Fisherman in the Exclusive Economic Zone of the Republic of Indonesia Natural Islands
}

\author{
Michelle Angelika S ${ }^{1}$,Yohanes Firmansyah ${ }^{2 *}$, Hanna Wijaya ${ }^{3}$, Yana Sylvana $^{4}$ \\ ${ }^{1234}$ Health Law Postgraduate Student, Pembangunan Negeri Veteran Jakarta \\ University
}

*Corresponding author: ${ }^{1}$ michelleangelika111@gmail.com, ${ }^{2}$ yohanesfirmansyah28@ gmail.com, ${ }^{3}$ hannwijaya@yahoo.com, ${ }^{4}$ sylvanayana@gmail.com,

\begin{abstract}
The territorial sea is the area of the sea zone closest to the coast, entirely subject to coastal sovereignty. Meanwhile, what is meant by the Economic Exclusive Zone is an area outside and adjacent to the territorial sea whose boundaries are 200 nautical miles measured from the base of the coast. The northern Natuna Islands are an Indonesian territorial area included in the Economic Exclusive Zone of the Republic of Indonesia. In areas that are the source of the power of nature are plentiful, including a source of power sea. It's led to interest from the foreigners to master the source power. The state of China announced that territory northwest china south is the territory of china based Map nine-dash line, which triggers the occurrence of the disputed territory of sea between Indonesia and china because it crosses the boundary north is Natuna Island the impact on the ships of foreign without permission to enter and steal the source power of nature in the Economic Exclusive Zone of the Republic of Indonesia because it is the actual effort of government Indonesia to eradicate illegal fishing both through relationship diplomacy maritime and businesses more. Researchers using qualitative descriptive research. The methodology of qualitative as the procedure of research that produces the descriptive data form of words written or spoken of people and behaviors that can be observed.
\end{abstract}

Keywords: Zona Exclusive Economy of the Republic of Indonesia, Diplomacy Maritime, illegal fishing 


\section{Introduction}

The history of the law of the sea, and other branches of law is made based on need, then survives and changes with changing governments and dynasties to be finally codified. Several concepts of the sea law are now known to have their roots in the civilization of the East Mediterranean. The elements included in it are insurance law, provisions related to rescue, sea transportation, compensation to seafarers due to work accidents, etc. This law also contains public maritime law, namely in the form of protection from robbers with warships against merchant ships to continue their trading voyages. ${ }^{1}$

Indonesia referred to the country with islands largest in the world, which has the area waters over much of the mainland, and Indonesia also is positioned strategically, namely between the ocean Indian and Ocean Pacific. However, the strategic position and the vastness of Indonesia's sea area can also create vulnerability to various maritime threats, including the illegal fishing case. Illegal fishing has an impact on the damage to the conservation of fish and the marine environment in Indonesia. Besides that, Indonesia also experiences economic losses due to illegal fishing. FAO data records Indonesia's annual losses of up to 30 trillion rupiahs. Still, then the information is considered by the Minister of Maritime Affairs and Fisheries, Susi Pudjiastuti, to be relatively small. According to his calculations, due to illegal fishing, the annual state loss could reach 240 trillion rupiah. ${ }^{2}$

Sea South China has an impact on the disruption security of the maritime area. It is caused by at announcement map nine-dash line ( nine lines dotted ), which is claimed as territorial China. Measures that raises criticism internationally, especially from countries that also claim (claimant states) most of the region Sea South China by because the primary claim not to use the rules of the law of the sea international (UNCLOS 1982), but such claims historically. Then China makes the region Sea South China entered the scope nine-dash line as an area of catching fish traditional or were referred to as "traditional fishing ground" who claimed to have lasted for thousands of years since before $\mathrm{AD}^{3}$

Natuna borders are direct with Sea South China, which currently is its status as the waters that overlap. Sea South China has the value of a political, economic, and defense are high. Although Indonesia did not become a country with a claim on Sea

1 Retno Windari, "Hukum Laut, Zona-Zona Maritim Sesuai UNCLOS 1982 Dan Konvensi-Konvensi Bidang Maritim," Seminar Nasional : Badan Koordinasi Keamanan Laut, 2009.

2 detikFinance, "Menteri Susi: Kerugian Akibat Illegal Fishing Rp 240 Triliun," 2014.

3 Zhiguo Gao and Bing bing Jia, "The Nine-Dash Line In The South China Sea: History, Status, and Implications," The American Journal of International Law 107 (2013). 
South China (Non-Claimant State), the nine-dash line that claimed China crosses the boundary north Zone Exclusive Economic (EEZ) of Indonesia in the waters of Natuna. That is where the problem lies between Indonesia and China. ${ }^{4}$

Claims overlap those made several times incidents occur. The experience aboard China entered the territorial waters of Natuna, one of which occurred on Saturday (12/09/2020) until the day this Sunday (09/13/2020). Ship Coast Guard ( guard beach) China with several gastric 5204 entered Natuna since at $10.00 \mathrm{am}$. Need to note that the Sea Natuna North is the area of jurisdiction of Indonesia, where Indonesia has a right to sovereignty over the source of the power of nature in the field of water. Foreign ships are allowed to cross on the condition that they do not carry out other activities contrary to national law. ${ }^{5}$

Islands Natuna indeed has the power attractiveness for countries other as potential sources of power nature are enormous. According to the data, the official Government of Regional District Natuna, regional Natuna, has the head of wealth of fishery sea that the results could reach more than 1 million tons/year. The field gas blocks D-Alpha, located $225 \mathrm{~km}$ to the north island of Natuna with total reserves 222 trillion cubic feet and gas hydrocarbons, which can be obtained for 46 trillion cubic feet of the sources of reserves of gas natural largest in Asia. ${ }^{6}$

In studying the relationship internationally, some words are not strangers to hear that " diplomacy, "according to Brownlie, diplomacy can mean a representative from each country- the country in shows, in particular, to implement an interaction or communication, build relationships, and conduct transactions political or legal. ${ }^{7}$

The sovereign rights of the Unitary State of the Republic of Indonesia are internationally regulated in Article 56 of the United Nations Convention on the Law of the Sea 1982, which provides special rights and jurisdiction to carry out exploration and exploitation, management and conservation of living natural resources in the Exclusive Economic Zone of the Coastal State. ${ }^{8}$ Simultaneously, the use of non-living natural resources is embraced in the legal regime of the Continental Shelf. It is nationally regulated in Article 4 paragraph (1) of Law Number 5 of 1983 concerning the Indonesian Exclusive Economic Zone, which

4 Muhammad Tri Andika and Allya Nur Aisyah, "Analisis Politik Luar Negeri Indonesia-China Di Era Presiden Joko Widodo: Benturan Kepentingan Ekonomi Dan Kedaulatan?," Indonesian Perspective 2, no. 2 (December 2017): 161, https://doi.org/10.14710/ip.v2i2.18477.

5 CNBC Indonesia, "Natuna Panas! Kapal China Kembali Masuk Laut RI,” CNBC Indonesia, 2020.

6 Pemerintah Daerah Kabupaten Natuna, "Membangun Kelautan Dan Perikanan Natuna," 2015.

7 Ian Brownlie, "Principles of Public International Law," Verfassung in Recht Und Übersee 14, no. 1 (1981): 92-93, https://doi.org/10.5771/0506-7286-1981-1-92.

8 United Nations Convention On The Law Of The Sea 1982 
indicates that the sovereign rights of the Unitary State of the Republic of Indonesia are only related to the exploration and exploitation of living natural resources. ${ }^{9}$

The concept of diplomacy maritime in the study is in addition to referring to the implementation of the pillars of diplomacy maritime in the administration of President Joko Widodo, also uses the approach of diplomacy maritime was raised by Christian Le Miere (2014), namely that a diplomacy marine is a tool that is used by force the sea and the Government of a country to achieve its interests. Miere also develop three typologies of diplomacy nautical, namely cooperative, persuasive, and coercive maritime diplomacy that runs through the various operations of maritime where maritime forces held the role of the principal as actor diplomacy maritime. ${ }^{10}$

Based on the description above, this paper will discuss how the chronology and substance of the dispute over the Economic Exclusive Zone between Indonesia and China in the Natuna Islands, what is the role of Indonesian maritime diplomacy, what is the dispute resolution effort on illegal fishing cases carried out by the Indonesian Government, what is the part of the Local Government in preventing illegal fishing, what the Government of Indonesia has taken preventive and repressive measures against the claims of China's nine-dash line map, what socialization is given to the public to prevent illegal fishing.

\section{Research Methods}

The study examines and analyzes the researchers use a type of research qualitative descriptive The qualitative as a procedure of research methodology that produces the descriptive data form of words written or spoken of people and behaviors observed. Automated collection of data is done by using the method of interview and review the literature.

\section{Results And Discussion}

\subsection{Chronology And Substance Of The Dispute Over The Economic} Exclusive Zone Between Indonesia And China In The Natuna Islands

This claim to the South China Sea was first formalized by the Chinese Government unilaterally in 1947. At that time, the Chinese Government firmly believed that the ownership status of the South China Sea belonged to China as a whole, especially knowing historical facts originating from the Ming Dynasty. Cheng

9 Undang-Undang Nomor 5 Tahun 1983 Tentang Zona Ekonomi Eksklusif Indonesia

10 Christian Le Miere, Maritime Diplomacy in the 21st Century: Drivers and Challenges, 2014. 
Ho, who sailed from Champa to the archipelago in 1405. The conflict map for the South China Sea region is divided into two areas. First, the Paracel archipelago is located in the northern part of the South China Sea. This conflict involves China, Taiwan, and Vietnam, which both claim ownership of these islands. The two Spratly islands have caused friction between China and 4 ASEAN countries, namely, the Philippines, Vietnam, Brunei Darussalam, and Malaysia, in the southern China Sea region. ${ }^{11}$

China's dominance in the South China Sea grew after US involvement in Vietnam officially ended with the Paris Peace Agreement in 1974. This is evidenced by the Chinese military forces occupying the western side of the Paracel Islands. They raised the flag and defeated the Vietnamese troops who were guarding there. The same is true of the Spratly Islands. To make the tensions lower between countries in the disputed area, a policy has been agreed on as a mandatory legal basis. A regular foundation is poured into the United Nations Convention on The Law of The Sea 1982 (UNCLOS), which emphasizes the territorial sovereignty of the South China Sea as far as 12 miles from the coast and the Exclusive Economic Zone (EEZ), which is 200 miles away. ${ }^{12}$

The United Nations policy in the form of UNCLOS did not work as expected, because China continued to insist that the South China Sea region, which covers hundreds of kilometers south and east of Hainan, which is also the southernmost province of China, belongs to them, and maintains its map they had made in 1947. Indonesia's efforts to mediate and resolve this conflict had started since 1990. Steps taken by Indonesia were to initiate a workshop to discuss the South China Sea dispute entitled Workshop for Managing Potential Conflict in The South China Sea. This workshop was held in Bali in 2002 to discuss the maritime code of conduct in the South China Sea (CoC) as a legal guideline that functions when a violation occurs with a disputing country in the South China Sea and a declaration of the behavior of each party. Disputes in the South China Sea or the Declaration on the Conduct in The South China Sea (DoC). ${ }^{13}$

After a series of incidents that occurred in the South China Sea region, negotiations were finally held in June 2016, in which the Ministry of Foreign Affairs of China stated that for the first time included Indonesia's exclusive economic zone

11 Joseph Victoryadi Kalembang, "ANALISIS SENGKETA ZONA EKONOMI EKSLUSIF ANTARA INDONESIA DAN RRT DI KEPULAUAN NATUNA," Journal of Politic and Government Studies, 2020.

12 Ibid

13 I Nyoman Sudira, "Konflik Laut Cina Selatan Dan Politik Luar Negeri Indonesia Ke Amerika Dan Eropa," Jurnal Ilmiah Hubungan Internasional Universitas Katolik Parabyangan, 2014. 
into its nine-line territory. Due to the increasing intention of disputes between China and ASEAN in the South China Sea region, in 2017, the idea of a maritime code of conduct or the Code of Conduct in the South China Sea $(\mathrm{CoC})$ was finally ratified. Apart from confirming the $\mathrm{CoC}$, this year's ASEAN meeting also discussed the Declaration on the Conduct of Parties in the South China Sea (DoC). Indonesia being part of the international community, feels the urgency in determining the best way to resolve disputes in the South China Sea. In this way, Indonesia can show its participation in maintaining world peace, which begins by creating peace in the country and these disputed areas. ${ }^{14}$

The national interests of Indonesia in the South China Sea are vital interests and primary interests. This interest is Indonesia's interest that cannot be negotiated because it involves the survival of the nation and state. These critical interests include sovereignty and sovereign rights in the marine area of national jurisdiction. UNCLOS (The United Nations Convention on the Law of The Sea) 1982 has regulated Indonesia's sovereignty and sovereign rights in Indonesia's jurisdictions bordering other countries, including sovereign rights for exploration, exploitation, management, conservation of natural resources, and protection of Indonesian citizens (Indonesian citizens) who are active around the border of the Republic of Indonesia (Republic of Indonesia) from violations of sovereignty and law, as well as threats of violence from claimant countries. ${ }^{15}$

Meanwhile, Indonesia's main interests that should be pursued in the context of international relations regulated in international law include guaranteed maritime security and safety of navigation for the international community who uses the area in the border area from the threat of violence and law violations accordingly. Applicable national and international laws. Besides, it is necessary to ensure the safety of suspects and victims in overcoming transnational organized crime in the border area of Indonesia and the South China Sea and providing environmental security for the international community using the site in the border area. ${ }^{16}$

\subsection{The Role of Indonesian Maritime Diplomacy}

The year 2009 until the year 2016 in the waters of Islands Natuna, according to the data from the (Rizka 2017), there were nine cases of Activities of Illegal Fishing by Fishermen China in the zone exclusively the economy of the Republic

\begin{tabular}{ll}
\hline 14 & Ibid \\
15 & Ibid \\
16 & Ibid
\end{tabular} 
of Indonesia waters of Islands Natuna is one case in the year 2009, two points in the year 2010, one point in the years 2012, 2013, 2015 and three patients in the year 2016. from the data, it is seen that threat the security of maritime Indonesia not only arise from the activity of illegal fishing, but also through actions the patrolling security northwest China that violate the rights of Sovereign Indonesia and seeks disturbing law enforcement in Indonesia's jurisdiction. According to Admiral Young Army National, I Indonesia Dr.Surya Wiranto s e nets n with the thought Miere (2014) concerning diplomacy flag or "showing the flag." "Showing the flag" is part of maritime diplomacy with a typology of persuasive naval diplomacy. The practice of illegal fishing that is done primarily by fishermen China can be suppressed if the ship's forces marine or boat component force maritime others with hoist flag of Indonesia attended as a tool or a marker of the existence of the state. In addition to the Army National Indonesia Navy, the investigator's Employees of State Civil (investigators) Fisheries and the National Security Marine also has the role of supervisor of security maritime by region zone entire economy of the Republic of Indonesia. $^{17}$

Board Security Marine, who now becomes one of the central institutions safeguarding the sea based on the mandate of the Constitution Act No. 32 of 2014 concerning Maritime Affairs, can also carry out a diplomatic function. The existence of Agency Safety Marine in maintaining the security of maritime now not only shown at the level of the domestic but also in the story of bilateral, regional, and global. The Agency for Safety Marine has been organizing the activities categorized as part of cooperative maritime diplomacy by implementing the Heads of Asian Coast Guard Agencies Meeting. Visit work Agency Security Sea as representative coast guard Indonesia to Beijing, China, in November 2016. Both efforts are a form of diplomacy maritime which has the goal to establish the relationship sufficiently, and each increase capacity building. Improved can create a sense of mutual trust so that the incident in illegal fishing by fishers of China like that has happened before can be avoided. ${ }^{18}$

Since the year 2016, the Government, Indonesia took the initiative to establish the Convention Regional about " Illegal, Unreported, and Unregulated Fishing (IUU)" Convention are expected to be created through the implementation of the Regional Conference on the Establishment of a Regional Convention against

17 Ela Riska, "Diplomasi Maritim Indonesia Terhadap Aktivitas Penangkapan Ikan Ilegal (Illegal Fishing) Oleh Nelayan China Di ZEEI Perairan Kepulauan Natuna," Jurnal Prodi Diplomasi Pertahanan 3, no. 2 (2017): 33-47.

18 Ibid 
Illegal, Unreported, Unregulated Fishing and Its Related Crimes are periodic. Apart from these efforts, the Indonesian Government will organize the Fisheries Crime Symposium ( FishCRIME) or the International Symposium on Fisheries Crime by the Indonesian Government through the Ministry of Marine Affairs and Fisheries. Diplomacy maritime cooperative this be an attempt Indonesia to work together with countries in the fight against crime illegal fishing. ${ }^{19}$

At the level of global, the governmental Indonesia expressed serious determination to combat IUU fishing. The entry Indonesia is the leading members of the FAO Council period 2012-2014 and are now given the opportunity back into a member of the Council for the period 2015-2018 indicate the level of confidence that the high of the organization is to the role of Indonesia in determining the goals of strategic FAO as the body of food and agricultural world one of which is taking care of the fisheries sector. Other efforts were also taken by the Indonesian Government through the ratification of the Agreement on Port State Measures to Prevent, Deter, and Eliminate Illegal, Unreported, and Unregulated Fishing. ${ }^{20}$

\subsection{Forms Of Dispute Resolution Efforts Against Illegal Fishing Cases Carried Out By The Government Of Indonesia}

In addition to the Government's efforts through policies guided by Law No.45 of 2009 on fisheries, the Indonesian Government has made various efforts to resolve illegal fishing disputes. $\mathrm{U}$ marsh that through: ${ }^{21}$

\section{Fishing Vessels Monitoring System}

System monitoring of ships carried out using the tools of technology high that function for monitor gestures out the entry of its vessels to the region Zone Economic Exclusive Indonesia, which is based on using the satellite. The system is installed on the boat fishing to see and know the whereabouts and identify what just what do ship it. Besides that, the system can function in a set of compliance vessels fishing against the rules. Indonesia enforcement system is done in stages, which stages. The first to build a system based on satellite Argos and build central monitoring of vessels fishing and perform the installation of the transmitter at 1500 units boat fishing.

$19 \mathrm{Ibid}$

20 Ibid

21 Bobby Bella Alamsyah, "Upaya Pemerintah Indonesia Dalam Menanggulangi Illegal Fishing Di Kepulauan Riau 2010-2015,” Ilmu Hubungan Internasional 5, no. 4 (2017): 1381-96. 


\section{The Role Of Local Government In Preventing Illegal Fishing}

The role of government areas in diplomacy maritime did not engage in active (is passive). Because both stakeholder interests are placing themselves as the party that does not have the authority in diplomacy maritime, then the diplomacy maritime, particularly in the field of illegal fishing, is the authority of the Government Center, and the head of the government area is set up and keep an eye on the level of the site alone. In the safety of maritime, government areas included in the category of sub-sectors of the country, which has the benefit will be the region (Stakeholders) where government areas as the agency that handles about marine and fisheries. Multiple Stakeholders ( stakeholder interests ) keys which had the authority is legal in terms of the decision -making about the security of maritime in the area is the Government District ( corresponding level) as an element of the executive, Representative of the Regional as an element of the legislature, and agencies areas such as the Department of Fisheries. According to the representative of the regional parliament of Natuna Regency, before the change in authority, the Natuna Regency Government had power over the sea from 0-4 miles. In comparison, the provincial Regional Government had power from 0-12 miles. ${ }^{22}$

The year 2016, the Government authority District northwest transferred the Regional Province because there is a change in the composition of the Organizational Rules of the work in the constitution number23 in 2014. Thus, since the Government of the Regional Province takes over the year such as licensing ( hoarding beach ), management, and related by sea, hand other, the contribution the Government of the District in participating and implementing security maritime namely to become an actor, is essential as the initiator of the program or policy of what is supposed to exist in the region were addressed to the Government Center (bottom to up). Furthermore, the Government District also became actors who support and implement programs created by the Government can be termed the of the District, the county, and for the District. ${ }^{23}$

\subsection{Preventive and Repressive Efforts made by the Government of Indonesia to claim the nine-line Map of China}

Preventative measures are preventive measures so that actions are taken previously do not happen again. What the Indonesian Government can do at this

\footnotetext{
22 Karya Sukrilawati, Christy Damayanti Damayanti, and GPH Dipokusumo, "PERAN PEMERINTAH DAERAH DALAM PENGEMBANGAN KEAMANAN MARITIM INDONESIA (Studi Kasus Pemberantasan Illegal Fishing Di Laut Natuna Tahun 2015-2017)" I (2018): 27-37.

23 Ibid
} 
time so that the Provocation incident in Indonesia's Natuna waters does not happen again are as follows: ${ }^{24}$

Conducted a diplomatic dialogue in which, on the one hand, China explained the claims of the Nine-Dashed Line map in a reasonable and logical legal basis. The Indonesian Government appointed Professor Hasyim Djalal, who is also a former senior Indonesian diplomat to the United Nations to become the head of the Indonesian delegation in the southern China sea dispute between Indonesia and China, to explain to the State of China that the waters in the Natuna Islands are included in the Sovereignty of the Unitary State of the Republic of Indonesia under the 1982 International Law of the Sea Convention. In the long term, increase the intensity of government administrative activities such as population registration and regional community services in the health and education sector on the Natuna Islands. The outermost people are proud and love the State of Indonesia. ${ }^{25}$

The repressive efforts made by the Government of the Unitary State of the Republic of Indonesia to enforce sovereign rights in the Exclusive Economic Zone over the claims of the China Nine-Dashed Line map is to continue to take firm action against perpetrators of illegal fishing who continue to fish in the Indonesian Exclusive Economic Zone. To show that law enforcement in the Unitary State of the Republic of Indonesia is carried out strictly. ${ }^{26}$

\subsection{Socialization To The Community To Prevent Illegal Fishing}

Socialization can be done by making a group of community watchdog groups of people who perform the supervision of the ongoing utilization of the source power of marine and fisheries. Following the Decree of Minister Number 58 In 2001, the group is an executor of supervision at the level of a field that consists of elements of figures public, religious leaders, indigenous leaders, Institutions communities, fishers, farmers. Establishment originated initiative. The church is facilitated by details of government areas and coordinated by a member of the group, which serves at once as a mediator between people and government/clerk. The task of the group is merely observing or monitoring (see, hear) the activities of fisheries and the utilization of the environment that exist in the area, then reported the alleged violation of the rule law fishery or suspected acts of crime in the field of

24 L.Tri Setyawanto R Calvin Agasta, Peni Susetyorini, "Hak Berdaulat Negara Kesatuan Republik Indonesia Di Kepulauan Natuna (Studi Khusus Indonesia Terhadap Klaim Peta Nine-Dashed Line China Di Kepulauan Natuna)," Diponegoro Law Journal 6, no. 2 (2017): 1-13.

25 Ibid

26 Ibid 
fishing to the Supervisory Fisheries or apparatus enforcement of the law. In running its duties, the group can relate directly to the commander, department of marine, and fishery up to the ministry of marine. Then can be given the socialization of the prohibition use tools to catch fish that are not a hospitable environment, A lat catch fish that are prohibited such as trawl tiger/trawl. ${ }^{27}$

\section{Conclusion}

Based on the results of the above discussion, it can be concluded in the form of The UN policy in the form of UNCLOS did not go as expected because China still insisted that the South China Sea region, which covers hundreds of kilometers south and east of Hainan, which is also the southernmost province of China, belongs to them, and still maintain the map they made in 1947. Regarding illegal fishing, the Indonesian Government, in its maritime diplomacy, can implement mechanisms in forums at the bilateral, regional, and global levels. At the bilateral level, communication and good relations between the marine forces of the two countries are implemented, one of which is through maritime diplomacy in the form of a navy to navy talks, HACGAM, visiting activities, and training.

The Government has also installed a satellite-based monitoring system in ships in stages to monitor vessel movements within the Indonesian Exclusive Economic Zone. Also not left behind is the role of local Government as a subsector of the state, which is interested in the region (Stakeholder) where the local Government is the agency that deals with maritime affairs and fisheries. Preventive and repressive measures taken by the Indonesian Government are conducting diplomatic dialogue, increasing administrative activities, and taking firm action against perpetrators of illegal fishing. Finally, the socialization given to the community to prevent illegal fishing is to form a community group to monitor and socialize the prohibition of using fishing gear that is not environmentally friendly.

\section{Conflict of Interest}

The authors declared that they have no conflicts of interest.

27 Nodi Marefanda and Afrizal Tjoetra, "STRATEGI PANGLIMA LAOT DALAM MENCEGAH ILLEGAL FISHING DI KABUPATEN ACEH BARAT,” Jurnal Public Policy 5 (2019). 


\section{Acknowledgments}

A big thank you to Diani Sadiawati, SH, LLM, PhD from the Department of International Law Pembangunan Nasional Veteran Jakarta University for guiding us in international law courses

\section{Author Contribution}

Michelle Angelika S played a role in sparking research ideas and making the manuscript. Yohanes Firmansyah contributed in making the manuscript and translating the language. Hanna Wijaya was in charge of finding journal compilation material. Yana Sylvana contributed to arranging the writing format and revising the manuscript

\section{Funding}

Self Funding

\section{Reference}

Agasta, Calvin, and Peni Susetyorini. "Hak Berdaulat Negara Kesatuan Republik Indonesia Di Kepulauan Natuna (Studi Khusus Indonesia Terhadap Klaim Peta Nine-Dashed Line China Di Kepulauan Natuna)," Diponegoro Law Journal 6, no. 2 (2017): 1-13.

Alamsyah, Bobby Bella. "Upaya Pemerintah Indonesia Dalam Menanggulangi Illegal Fishing Di Kepulauan Riau 2010-2015,” Ilmu Hubungan Internasional 5, no. 4 (2017): 1381-96.

Andika, Muhammad Tri, and Allya Nur Aisyah. "Analisis Politik Luar Negeri Indonesia-China Di Era Presiden Joko Widodo: Benturan Kepentingan Ekonomi Dan Kedaulatan?," Indonesian Perspective 2, no. 2 (December 2017): 161, https://doi.org/10.14710/ip.v2i2.18477.

Brownlie, Ian . "Principles of Public International Law," Verfassung in Recht Und Übersee 14, no. 1 (1981): 92-93, https://doi.org/10.5771/0506-7286-1981$1-92$.

CNBC Indonesia, "Natuna Panas! Kapal China Kembali Masuk Laut RI," CNBC Indonesia, 2020.

DetikFinance, "Menteri Susi: Kerugian Akibat Illegal Fishing Rp 240 Triliun," 2014. 
Michelle Angelika S, Yohanes Firmansyah, Hanna Wijaya, Yana Sylvana

Gao, Zhiguo, and Bing Bing Jia, "The Nine-Dash Line In The South China Sea: History, Status, and Implications," The American Journal of International Law 107 (2013).

Kalembang, Joseph Victoryadi. "ANALISIS SENGKETA ZONA EKONOMI EKSLUSIF ANTARA INDONESIA DAN RRT DI KEPULAUAN NATUNA," Journal of Politic and Government Studies, 2020.

Marefanda, Nodi, and Afrizal Tjoetra. "STRATEGI PANGLIMA LAOT DALAM MENCEGAH ILLEGAL FISHING DI KABUPATEN ACEH BARAT,” Jurnal Public Policy 5 (2019).

Miere, Christian Le. Maritime Diplomacy in the 21st Century: Drivers and Challenges, 2014.

Pemerintah Daerah Kabupaten Natuna, "Membangun Kelautan Dan Perikanan Natuna," 2015.

Riska, Ela. "Diplomasi Maritim Indonesia Terhadap Aktivitas Penangkapan Ikan Ilegal (Illegal Fishing) Oleh Nelayan China Di ZEEI Perairan Kepulauan Natuna," Jurnal Prodi Diplomasi Pertahanan 3, no. 2 (2017): 33-47.

Sudira, I Nyoman. "Konflik Laut Cina Selatan Dan Politik Luar Negeri Indonesia Ke Amerika Dan Eropa," Jurnal Ilmiah Hubungan Internasional Universitas Katolik Parahyangan, 2014.

Sukrilawati, Karya, Christy Damayanti Damayanti, and GPH Dipokusumo, "PERAN PEMERINTAH DAERAH DALAM PENGEMBANGAN KEAMANAN MARITIM INDONESIA (Studi Kasus Pemberantasan Illegal Fishing Di Laut Natuna Tahun 2015-2017)” I (2018): 27-37.

Undang-Undang Nomor 5 Tahun 1983 Tentang Zona Ekonomi Eksklusif Indonesia

United Nations Convention On The Law Of The Sea 1982

Windari, Retno . "Hukum Laut, Zona-Zona Maritim Sesuai UNCLOS 1982 Dan Konvensi-Konvensi Bidang Maritim," Seminar Nasional: Badan Koordinasi Keamanan Laut, 2009. 
